\title{
Prolonged jaundice and hypothyroidism as the presenting symptoms in a neonate with a novel Prop 1 gene mutation (Q83X)
}

\author{
Antonis Voutetakis, Maria Maniati-Christidi, Christina Kanaka-Gantenbein, Maria Dracopoulou, \\ Maria Argyropoulou, Sarantis Livadas, Catherine Dacou-Voutetakis and Amalia Sertedaki \\ Endocrine Unit, First Department of Pediatrics, Athens University Medical School, Aghia Sophia Children's Hospital, Goudi, Athens 115 27, Greece \\ (Correspondence should be addressed to A Sertedaki; Email: aserted@med.uoa.gr)
}

\begin{abstract}
Objective: To identify the genetic defect in a neonate presented with prolonged jaundice and central hypothyroidism.

Design: Central hypothyroidism was detected in a neonate initially examined for prolonged jaundice, and levothyroxine therapy was initiated. Direct sequencing of the Prop1 gene was carried out and pituitary function and morphology were evaluated using hormonal testing and magnetic resonance imaging (MRI) respectively.

Methods: Dynamic hormonal testing was carried out using established methodologies. Hormones were determined by RIA or chemiluminescence immunoassays. Genomic analysis of the Prop1 gene was performed by direct sequencing. MRI protocol: sagittal spin echo T2-weighted scans 2500/90 (TR/TE), plain and contrast-enhanced sagittal and coronal spin echo T1-weighted scans 500/20 (TR/TE).

Results: Low thyroid hormones (coupled with lack of TSH rise), low GH, normal cortisol and normal prolactin values were detected. Direct sequencing revealed the presence of two mutations in the Prop1 gene: GA296del and Q83X. The Q83X was further confirmed by PvuII restriction digestion and represented a novel Prop1 gene mutation, which was not detected in 100 controls tested. Pituitary enlargement was detected, with respect to normal-for-age controls.

Conclusions: (i) The Q83X mutation extends the spectrum of Prop1 gene mutations; (ii) central hypothyroidism in a neonate might constitute the initial sign of Prop1 gene defect; (iii) the patient is the youngest individual with Prop1 gene defect and pituitary enlargement presented to date; and (iv) early detection of Prop1 gene mutations facilitates genetic counseling and ensures prompt management of the anticipated hormonal insufficiencies.
\end{abstract}

European Journal of Endocrinology 150 257-264

\section{Introduction}

The ontogenesis of the anterior pituitary gland constitutes a complex and multifarious process. The most important transcription factors guiding the evolution of the adenohypophysis are: Hesx1 (1), Pitx1 (2), Pitx2 (3), Lhx3 (4), Lhx4 (5), Prop1 (6) and Pit1 (POU1F1) (7). Mutations in these tissue-specific transcription factors cause insufficient synthesis of more than one pituitary hormone.

The Prop1 gene is located on chromosome 5q35, consists of three exons and two introns and encodes a protein of 226 amino acids (6). The various molecular defects of the Prop1 gene, thus far reported, are deletions or substitutions in the DNA-binding domain (exons 2 and 3), in the transcriptional activation domain (exon 3) and in the intron-exon boundaries $(8-15)$. The most frequently observed Prop1 gene mutation is a GA deletion at nucleotide 296 (GA296del) (16-17). Pathogenic Prop1 gene alterations lead to combined pituitary hormone deficiency (CPHD): growth hormone (GH), prolactin (PRL), thyrotropin (TSH) and gonadotropins of variable severity and timing of onset. Adrenocorticotropin insufficiency occasionally develops as a rather late manifestation of unknown pathogenesis $(11,12,18,19)$. Insufficient adrenarche in the presence of a normal pituitary-adrenal axis has also been reported (20). Pituitary morphology in patients with Prop1 gene defects varies: a normal pituitary gland has been demonstrated in some cases, while in others pituitary hypoplasia, hyperplasia or adenoma have been detected $(12,21-23)$.

In the present communication, we describe an infant presented with prolonged neonatal jaundice and low thyroid hormones, without TSH rise, caused by compound heterozygosity of the Prop1 gene. One of the 
mutations detected (Q83X) constitutes a novel Prop1 gene defect.

\section{Patient and methods}

\section{Patient presentation, evaluation and treatment}

The infant was born at term following an uneventful pregnancy and normal delivery to a gravida II para II mother. He cried immediately and no perinatal or neonatal problems were noted. The birth weight was $3300 \mathrm{~g}$ and the birth length was $52 \mathrm{~cm}$. The neonatal screening for congenital hypothyroidism (using TSH determination) was normal, as expected.

The parents were healthy and reportedly unrelated. The father's height was $179 \mathrm{~cm}$, the mother's $157 \mathrm{~cm}$ and the infant's target height was $174.5 \mathrm{~cm}$ (standard deviation score: -0.4 ). The patient's older sister, aged 3 years, was healthy and of normal linear growth. She was operated upon for thyroglossal cyst at the age of 2 years.

The patient was initially examined at the age of 40 days because of prolonged jaundice and elevated liver enzymes. At the time, he was exclusively breast-fed. The total bilirubin (normal value $(\mathrm{NV})<1 \mathrm{mg} / \mathrm{dl}$ ) was $8.2 \mathrm{mg} / \mathrm{dl}$ (direct $0.7 \mathrm{mg} / \mathrm{dl}$ ). The liver enzymes were serum glutamic-oxaloacetic transaminase (SGOT): $106 \mathrm{IU} / \mathrm{l}$ (NV: 10-60 IU/l), serum glutamic-pyruvic transaminase (SGPT): $42 \mathrm{IU} / \mathrm{l}(\mathrm{NV}: 5-45 \mathrm{IU} / \mathrm{l}), \gamma$-glutamyltransferase ( $\gamma \mathrm{GT}): 100 \mathrm{IU} / \mathrm{l}(\mathrm{NV}: 2-50 \mathrm{IU} / \mathrm{l})$ and the alkaline phosphatase was $310 \mathrm{IU} / \mathrm{l}$ (NV: 60-240 IU/l). Laboratory tests performed for hemolytic disease, hepatitis and congenital infections proved negative. As part of the diagnostic work up for the prolonged jaundice, the thyroid hormones were determined and the following results obtained: total thyroxine (T4) (TT4): $68.2 \mathrm{nmol} / \mathrm{l}$ (NV: $94-243 \mathrm{nmol} / \mathrm{l})$, free T4 (FT4): $8.9 \mathrm{pmol} / \mathrm{l}(\mathrm{NV}: 14.2-25.7 \mathrm{pmol} / \mathrm{l})$, total triiodothyronine (T3) (TT3): $2.34 \mathrm{nmol} / \mathrm{l}(\mathrm{NV}: 1.54-3.77 \mathrm{nmol} / \mathrm{l})$, TSH: $2.9 \mathrm{mIU} / \mathrm{l}$ (NV: $0.5-6.46 \mathrm{mIU} / \mathrm{l})$.

The infant was transferred to our endocrine unit at the age of 11 weeks. The physical examination showed the following: the body length was $58 \mathrm{~cm}$, the weight $6 \mathrm{~kg}$ and the head circumference $40.5 \mathrm{~cm}$. The anterior fontanel measured $2.5 \times 2.5 \mathrm{~cm}$. No clinical features of hypothyroidism were present except for mildly icteric conjuctivae. The testes (volume: $1.5 \mathrm{ml}$ ) were in situ and the penile length was normal. The rest of the physical examination was unremarkable. The thyroid hormones were low with no TSH increment (Table 1). The total bilirubin value was $2.4 \mathrm{mg} / \mathrm{dl}$ (direct $0.7 \mathrm{mg} / \mathrm{dl}$ ) and the liver enzymes were: SGOT: $170 \mathrm{IU} / \mathrm{l}$, SGPT: $125 \mathrm{IU} / \mathrm{l}$ and $\gamma \mathrm{GT}$ : $84 \mathrm{IU} / \mathrm{l}$. Levothyroxine therapy was initiated at the age of 12 weeks $(25 \mu \mathrm{g} /$ day, which was raised to $50 \mu \mathrm{g} /$ day at the age of 10 months). Thereafter, the thyroid hormone values have always been normal.
Table 1 Hormonal findings at different ages: pituitary-thyroid axis.

\begin{tabular}{lccc}
\hline Hormone & $\begin{array}{c}\text { Week 11 } \\
\text { (pre-treatment) }\end{array}$ & $\begin{array}{c}\text { Week 14 } \\
\text { (post-levothyroxine) }\end{array}$ & Normal values \\
\hline TT4 $(\mathrm{nmol} / \mathrm{l})$ & 88.8 & 184 & $90-206$ \\
TT3 $(\mathrm{nmol} / \mathrm{l})$ & 2.60 & 3.87 & $1.54-4.00$ \\
FT4 $(\mathrm{pmol} / \mathrm{l})$ & 8.5 & 21.6 & $12.9-29.6$ \\
TSH $(\mathrm{mlU} / \mathrm{l})$ & 3.7 & 0.3 & $0.8-8$ \\
\hline
\end{tabular}

At the age of 16 weeks the liver enzymes were normal (SGOT: 45 IU/l, SGPT: 32 IU/l and $\gamma$ GT: 39 IU/l).

The linear growth pattern before and after levothyroxine initiation is depicted in Fig. 1. The infant's psychomotor development has been normal: he spoke his first words at the age of 10 months, walked at the age of 12 months, and formed three-word sentences at the age of 2 years. Due to the progressive failure of the linear growth curve we are in the process of starting human GH substitution therapy.

\section{Hormonal studies}

At 40 days, serum TT4, FT4, TT3 and TSH were determined using the electrochemiluminesence immunoassay method (Roche). At 11 weeks, FT4 and TSH were determined using the Nichols Advantage Chemiluminescence Immunoassay (Nichols Institute Diagnostics, San Juan Capistano, CA, USA). PRL, luteinizing hormone (LH) and follicle-stimulating hormone (FSH) were determined using the Automated Chemiluminesence System ACS: 180 (Bayer, Tarrytown, NY, Europe).

Cortisol, GH and insulin-like growth factor-I (IGF-I) were determined using the Nichols Advantage Chemiluminesence Immunoassay. Dehydroepiandrosterone sulfate (DHEAS) and testosterone were determined by RIA (Diagnostic Systems Laboratories, Webster, TX, USA).

The glucagon test was carried out after the i.m. administration of glucagon $(100 \mu \mathrm{g} / \mathrm{kg})$. Blood samples for $\mathrm{GH}$ and cortisol determinations were obtained prior to and $60,90,120,150$ and $180 \mathrm{~min}$ post-glucagon administration.

The gonadotropin-releasing hormone (GnRH) test was carried out after the i.v. administration of synthetic GnRH $(100 \mu \mathrm{g})$. Blood samples for LH and FSH determinations were obtained prior to and 30 and $60 \mathrm{~min}$ post-GnRH administration.

The TRH test was carried out after the i.v. administration of synthetic TRH $(200 \mu \mathrm{g})$. Blood samples for TSH and PRL determinations were obtained prior to and 30 and $60 \mathrm{~min}$ post-TRH.

\section{Pituitary magnetic resonance imaging (MRI)}

The MRI protocol consisted of sagittal spin echo T2-weighted scans 2500/90 (TR/TE), and plain 

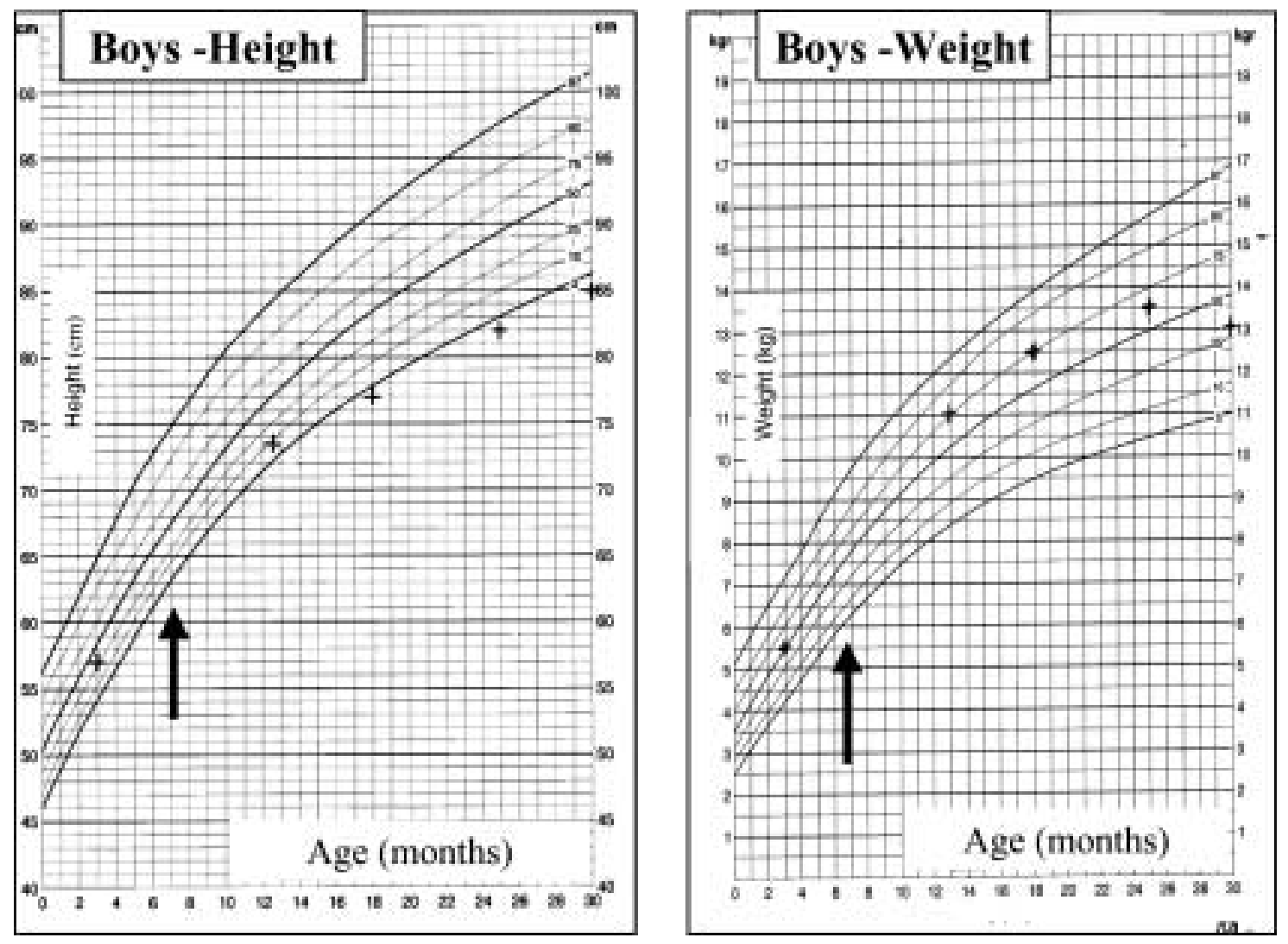

Figure 1 The infant's height and weight curves. The arrows indicate the initiation of levothyroxine therapy.

and contrast-enhanced sagittal and coronal spin echo T1-weighted scans 500/20 (TR/TE), with slice thickness $3 \mathrm{~mm}$ and $0.3 \mathrm{~mm}$ gap. The maximum height of the pituitary gland was measured perpendicular to the sella turcica. The pituitary gland was considered hypoplastic if the maximum height was less than -2 S.D. and hyperplastic if the maximum height was greater than 2 S.D., compared with normal controls $(24,25)$.

\section{Genomic analysis of the Prop1 gene}

The study was approved by the institutional review board and informed consent was obtained from each participant or their parents. One hundred control subjects were also included in the study. DNA was extracted from peripheral blood using the QIAmp DNA Blood mini kit (Qiagen, Hilden, Germany). Each one of the three exons of the Prop1 gene was PCR amplified. PCR was performed in a $50 \mu \mathrm{l}$ reaction mixture containing $100 \mathrm{ng}$ DNA, $25 \mu \mathrm{l}$ Promega Mastermix (Promega Corporation, Madison, WI, USA) and $25 \mathrm{pmol}$ of each primer. The following pairs of primers were used: exon 1 sense primer 5'-GAGCTGCGGAAGCAGAGAAATCTCA-3', antisense primer 5'-AGAGGTAACTGTCTCACATCCCCAC-3'; exon 2 sense primer $5^{\prime}$-cactgagcgcaatcccgggac- $3^{\prime}$, antisense 5'-gagatgaggcctgtgtctggtga-3'; and exon 3 sense primer $5^{\prime}$-ctcttgtcattggagtagggtgtca- $3^{\prime}$, antisense primer $5^{\prime}$-cagacttcctccactaatcaccca- $3^{\prime}$.

PCR amplification reaction consisted of one cycle at $94^{\circ} \mathrm{C}$ for $3 \mathrm{~min}$ followed by 35 cycles of $30 \mathrm{~s}$ at $94^{\circ} \mathrm{C}$, $30 \mathrm{~s}$ at $56^{\circ} \mathrm{C}, 1 \mathrm{~min}$ at $72^{\circ} \mathrm{C}$ and one cycle of $5 \mathrm{~min}$ at $72{ }^{\circ} \mathrm{C}$. The PCR products were cleaned with the Qiaquick PCR purification kit (Qiagen). The double-stranded PCR products of each exon were directly sequenced employing the Thermo Sequenase core sequencing kit on a VISTRA DNA Sequencer 725 (Amersham Pharmacia Biotech) using the following Texas Red-labeled primers: exon 1: 1S 5'-CCAAGGGGTGCTCCAGTC-3' (sense),

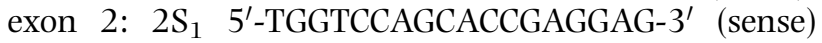
and $2 \mathrm{~S}_{2}:$ 5'-TGCCCAACATTCTATGATAGC-3' (anti sense) and exon 3: $3 \mathrm{~S}_{1}$ : 5'-GTGGGCTCTGATGTGGTTC-

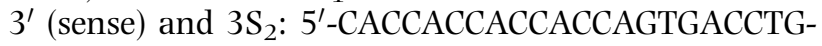
$3^{\prime}$ (sense).

\section{Detection of the Q83X mutation by PuII restriction digestion of exon 2}

PCR products were digested with $10 \mathrm{U}$ PvuII (New England Biolabs, Hertfordshire, UK) at $37^{\circ} \mathrm{C}$ overnight. The resulting fragments (230 and $210 \mathrm{bp})$ were analyzed in 4\% (w/v) 3:1 NuSieve:Seakem (BMA BioProducts, Rockland, MD, USA) agarose gel and visualized by ethidium bromide staining. 


\section{Results}

\section{Hormonal studies}

Hormonal studies showed low thyroid hormone values coupled with 'normal' TSH values at week 11 . Ten days after levothyroxine initiation the thyroid hormone values were normal (Table 1 ).

The GH values were low and the cortisol values were normal after the glucagon test (18 months, Table 2). IGF-I values were very low (Table 3 ). The basal PRL values were normal at the age of 13 and 18 months and lower at 24 months with a small rise post-TRH (Tables 2 and 3). The basal gonadotropin values were within the normal range for the corresponding age, but the response to GnRH at 24 months was not adequate (Tables 2 and 3). Low normal testosterone value and normal DHEAS value were detected at the age of 3 months (Table 3 ).

\section{MRI}

The MRI of the pituitary gland, carried out at the age of 2.5 years, showed pituitary enlargement (Fig. 2A and B). The pituitary gland height was $8 \mathrm{~mm}$ (normal $4.0 \pm 0.7 \mathrm{~mm}$ ) (24) with no abnormalities of the neurohypophysis, the optic chiasm or the pituitary stalk.

\section{Molecular studies}

Direct sequencing of exon 2 of the Prop1 gene with two different primers (one in the sense and one in the antisense direction) revealed that the patient was a compound heterozygote for the mutation GA296del, inherited from his father, and the mutation C247T, inherited from his mother (Fig. 3). The C247T transition converts codon 83 (CAG) encoding glutamine into a termination codon (TAG) and constitutes a novel nonsense mutation (Q83X). This mutation should result in the production of a truncated peptide with only 82 of the 226 amino acids of the wild-type protein. The C247T mutation destroys a PvuII restriction site (CAG/CTG) and allows for the confirmation of the DNA sequencing results by restriction digestion. Hence, the absence of the PvuII restriction site confirmed the presence of the mutation (Fig. 4). Importantly, the mutation Q83X has not been detected in 100 DNA samples tested in our laboratory.

\section{Discussion}

We describe a full-term neonate presented with prolonged jaundice and elevated liver enzymes. The low values of thyroid hormones, coupled with lack of TSH rise, led to the tentative diagnosis of congenital central hypothyroidism: TRH receptor defects (26), alterations in the TSH $\beta$-subunit $(27,28)$, or pituitary-specific transcription factors, such as Prop1 and Pit1 (29). Direct sequencing of the Prop1 gene revealed the specific pathogenic mutations. Later on, $\mathrm{GH}$ deficiency was suspected due to the absence of growth acceleration after levothyroxine therapy initiation, the declining growth curve and the low height with respect to the infant's

Table 2 Hormonal findings at different ages: dynamic tests.

\begin{tabular}{|c|c|c|c|c|c|c|}
\hline \multirow[b]{2}{*}{ Time of sampling (min) } & \multicolumn{2}{|c|}{ Glucagon (age 18 months) } & \multicolumn{2}{|c|}{ GnRH (age 24 months) } & \multicolumn{2}{|c|}{ TRH (age 24 months) } \\
\hline & $\mathrm{GH}(\mu \mathrm{g} / \mathrm{l})$ & Cortisol (nmol/l) & $\mathrm{LH}(\mathrm{IU} / \mathrm{I})$ & FSH (IU/I) & TSH (mlU/l) & $\mathrm{PRL}(\mu \mathrm{g} / \mathrm{l})$ \\
\hline 0 & 2.1 & 635 & 0.1 & 0.9 & 0.2 & 7.6 \\
\hline 30 & - & - & 0.2 & 1.1 & 0.8 & 13.9 \\
\hline 60 & 1.4 & 524 & 0.3 & 1.3 & 1.0 & 12.8 \\
\hline 90 & 1.6 & 386 & - & - & - & - \\
\hline 120 & 2.6 & 414 & - & - & - & - \\
\hline 150 & 3.2 & 855 & - & - & - & - \\
\hline 180 & 2.8 & 1021 & - & - & - & - \\
\hline Peak normal values & $>10$ & $>690$ & $1.4-6.0$ & $2.3-6.9$ & $>10$ & $>20$ \\
\hline
\end{tabular}

$\mathrm{LHRH}$, luteinizing hormone-releasing hormone. - , values not required for the times indicated.

Table 3 Hormonal findings at different ages: other hormonal findings.

\begin{tabular}{|c|c|c|c|c|c|}
\hline & \multicolumn{4}{|c|}{ Age (months) } & \multirow[b]{2}{*}{ Normal values } \\
\hline & 3 & 13 & 18 & 24 & \\
\hline Testosterone (nmol/l) & 1.59 & - & - & - & $1.1-5.0$ (3-5 months) \\
\hline DHEAS (nmol/l) & 1200 & - & - & - & $117-3020$ ( < 1 year) \\
\hline LH Basal (IU/I) & - & $<0.01$ & 0.06 & - & $<3.4$ \\
\hline FSH Basal (IU/I) & - & 0.9 & 0.7 & - & $0.2-1.8$ \\
\hline PRL Basal ( $\mu \mathrm{g} / \mathrm{l})$ & - & 15.3 & 16.3 & - & $9.8-73.5$ \\
\hline IGF-I $(\mu \mathrm{g} / \mathrm{I})$ & - & - & - & 1.0 & $17-248$ \\
\hline
\end{tabular}




$$
\text { (A) }
$$

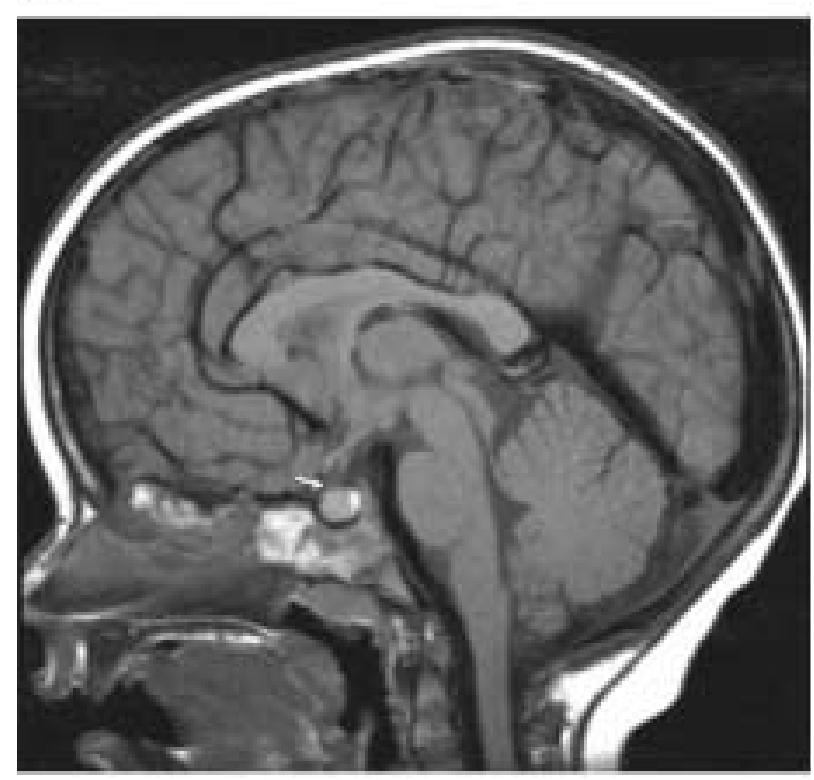

(日)

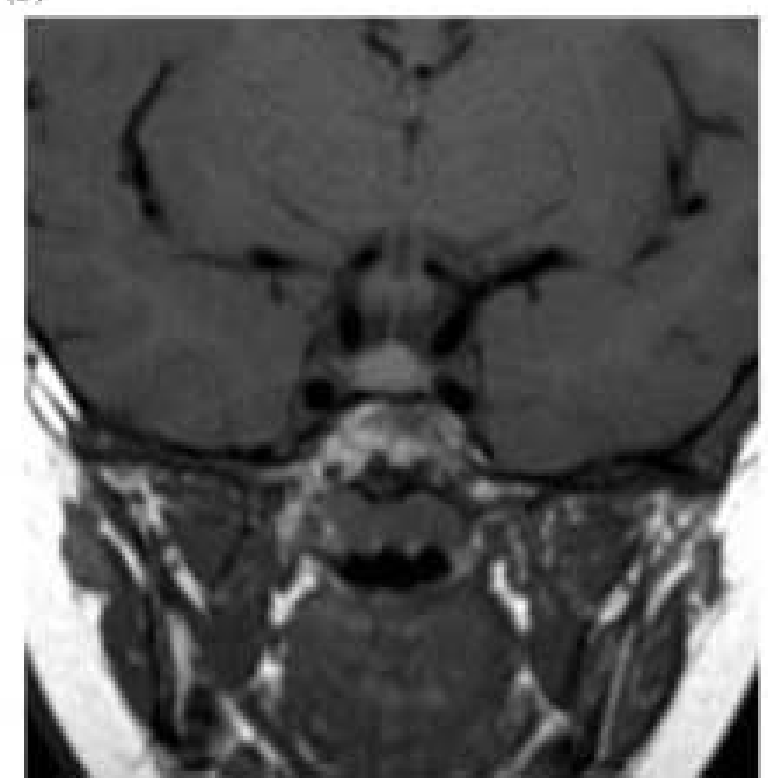

Figure 2 Pituitary MRI of the patient with Prop1 gene defect (GA296del/Q83X). (A) Midsagittal plain T-weighted MRI scan shows pituitary enlargement with anterior displacement of the pituitary stalk (white arrow). The posterior lobe is in the normal position and exhibits a normal bright signal. (B) Coronal plain T1-weighted MRI scan shows pituitary gland enlargement without lateral deviation of the stalk.

genetic potentials. GH deficiency, and therefore CPHD, was confirmed using appropriate studies (Tables 1-3).

The molecular studies revealed compound heterozygosity for the mutations GA296del and Q83X; the latter reported for the first time. The novel mutation Q83X is a C to T transition at nucleotide 247 located in exon 2, resulting in a premature stop codon (CAG to TAG). The Q83X mutation is located in the highly

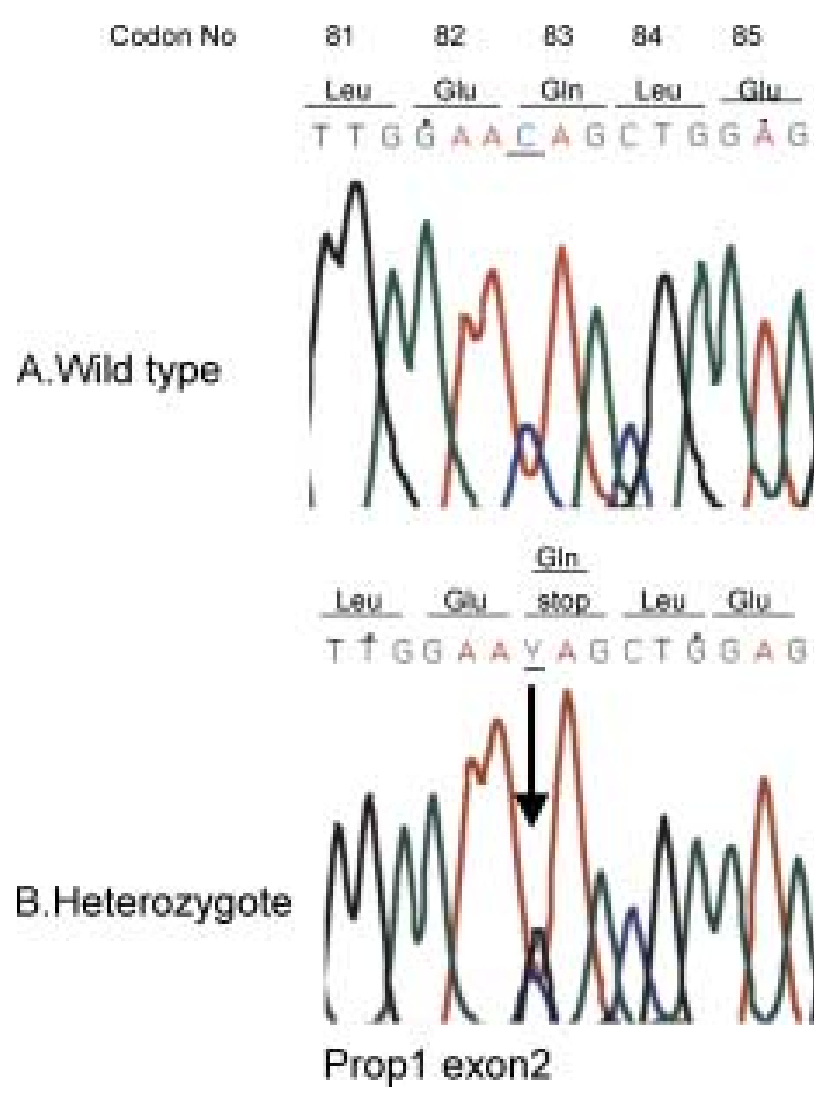

Figure 3 Part of the automated fluorescence-based sequencing chromatogram of the second exon of Prop1 gene amplified from genomic DNA of $(A)$ a normal individual and $(B)$ the patient, heterozygous for the mutation Q83X. Normal (CAG) and mutant (YAG), nucleotide 247 is underlined. $Y$ denotes $\mathrm{C}$ or $\mathrm{T}$.

conserved $\alpha-1$ helix of the homeodomain that extends from amino acid 69 to amino acid 128. A comparison of this conserved amino acid sequence employing a Blast search (30) was carried out (SIB BLAST Network Service) and revealed that glutamine at codon 83 is conserved in several species: bovine, mouse, pig, dog and rat. Moreover, the protein resulting from this mutation is a truncated protein with only 82 out of the 226 amino acids forming the normal peptide. The functional consequences of this novel mutation are obvious since the truncated protein lacks both functional domains of the wild-type protein: the DNA-binding domain and the transactivation domain. It must be mentioned that previously reported mutations downstream of codon 83 result in truncated proteins, with complete loss of function (8). Therefore, the Q83X mutation should preclude binding of the transcription factor to its cognate DNA sites and result in complete loss of function. Alternatively, the nonsense transcript might not be translated to a truncated protein, but rather become degraded by the cell via the nonsensemediated mRNA decay pathway (31). Importantly, the $\mathrm{C}$ to $\mathrm{T}$ transition at nucleotide 247 was not found in 100 normal individuals tested, excluding the possibility of a polymorphism. 


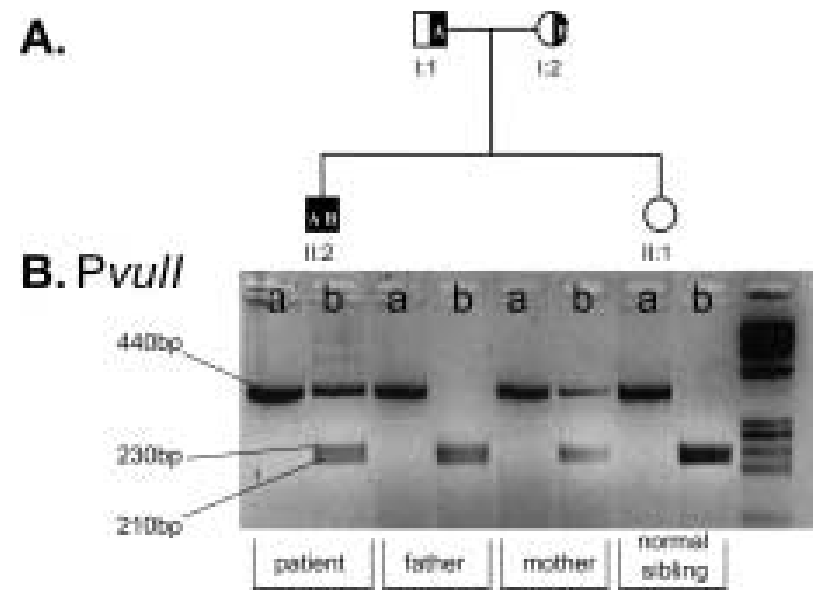

Figure 4 (A) Family pedigree. (B) Results after Pvull restriction digestion of PCR products. Photograph of ethidium bromidestained $4 \%$ agarose gel (Nusieve:Seakem 3:1) after electrophoresis of the PCR amplification product of exon 2 of the Prop1 gene (a) undigested and (b) after Pvull restriction digestion. Restriction digestion of the wild-type PCR product results in two bands (230 and $210 \mathrm{bp}$ ). The patient and his mother are heterozygotes for the Q83X mutation, which destroys the Pvull restriction site. Their PCR products exhibit three bands after restriction digestion: the $440 \mathrm{bp}$ band (due to the presence of the mutant allele; same size as the undigested PCR product) and the 230 and $210 \mathrm{bp}$ bands (due to the presence of the wild-type allele). The PCR products of both the father and the unaffected daughter (neither carrying the Q83X mutation) are completely digested by Pvull, as expected, and exhibit only the 230 and 210 bp bands. The absence of the Pvull restriction site confirms the presence of the Q83X mutation.

The second mutation detected in our patient (GA296del) is the most frequently observed mutation in nearly all populations studied to date. It is a frameshift mutation also resulting in a premature stop codon (S109X) and is considered to be a complete loss-of-function mutation. The high frequency of the GA296del mutation is not related to a founder effect since it occurs independently in different populations (32). GA296del involves a series of three GA repeats that misalign during DNA replication, generating slippage and deletion.

Patients with Prop1 gene defects, thus far reported, were evaluated because of growth failure and low TSH hypothyroidism later in childhood. In only one case was low TSH hypothyroidism diagnosed at the age of 12 months (33). Although prolonged jaundice is within the spectrum of signs expected in neonates with either hypothyroidism or GH insufficiency, jaundice as a sign leading to the evaluation of Prop1 gene has not thus far been reported.

In full-term infants of normal birth weight, exhibiting low or borderline thyroid hormones with no TSH increase, the diagnosis of central hypothyroidism, isolated or as part of CPHD must be considered. It is of interest to mention that the thyroid hormone values were low despite normal TSH values. The occurrence of normal or even slightly elevated values of TSH in cases of central hypothyroidism has been attributed to the presence of biologically inactive TSH molecules (34). In our patient, the moderate elevation of hepatic transaminases in the absence of an obvious pathogenetic mechanism, as well as their normalization shortly after euthyroidism was accomplished, must be attributed to hypothyroidism $(35,36)$. From the reports available, it has become evident that in patients with Prop1 gene defect, the severity and timing of hormonal insufficiency varies with no particular correlation between phenotype and genotype (33). In this regard, it is of interest to underscore certain features of the present case. The low normal testosterone levels in our infant at the age of 3 months indicate that, at least at this developmental stage, the testicular function was satisfactory. The normal penile size is confirmatory and favors the prediction of Parks et al. (29) that the size of the penis should be normal in infants with Prop1 gene defects. The normal-for-age value of DHEAS compared with insufficient function of the reticular zone (insufficient adrenarche) in pubertal and post-pubertal subjects with a Prop1 gene defect (20) constitutes an interesting observation. It can be attributed to diverse regulation of DHEAS production by the fetal and adult adrenals or possibly to later development of this insufficiency, as has also been reported for other hormones in Prop1-deficient patients. Furthermore, the basal PRL values in our patient were normal while in older patients they are usually reported as quite low (29). With regard to the gonadotropins, subnormal values in this age group are difficult to diagnose, since expected values are generally low (37).

The pituitary enlargement found in our patient has also been described in other cases with Prop1 gene defects $(13,21,23,38)$. However, we must underscore the very young age (2.5 years) at which the enlargement was detected in our patient, a finding indicative of an early initiation of the process responsible for the pituitary enlargement. Hence, it should be kept in mind that pituitary enlargement can occur quite early in patients with Prop1 gene defect and should be considered in the differential diagnosis of a pituitary mass or enlargement. The mechanism involved still remains enigmatic and quite speculative.

In conclusion: (i) the Q83X mutation extends the spectrum of Prop1 gene mutations; (ii) central hypothyroidism in a neonate might constitute the initial sign of Propl gene defect; (iii) the patient is the youngest individual with Prop1 gene defect and pituitary enlargement presented to date; and (iv) early detection of Prop1 gene mutations facilitates genetic counseling and ensures prompt management of the anticipated hormonal insufficiencies.

\section{References}

1 Thomas PQ, Dattani MT, Brickman J, McNay D, Warne G, Zacharin $\mathrm{M}$ et al. Heterozygous HESX1 mutations associated 
with isolated congenital pituitary hypoplasia and septo-optic dysplasia. Human Molecular Genetics 200110 39-45.

2 Szeto DP, Rodriguez-Estaban C, Ryan AK, O'Connell SM, Liu F, Kioussi $\mathrm{C}$ et al. Role of Bicoid-related homeodomain factor Pitx1 in specifying hindlimb morphogenesis and pituitary development. Genes and Development 199913 484-494.

3 Semina EV, Reiter R, Leysens NJ, Alward WL, Small KW, Datson NA et al. Cloning and characterization of a novel bicoidrelated homeobox transcription factor gene, RIEG, involved in Rieger syndrome. Nature Genetics $199614392-399$.

4 Netchine I, Sobrier ML, Krude H, Schnabel D, Maghnie M, Marcos E et al. Mutations in the LHX3 result in a new syndrome revealed by combined pituitary hormone deficiency. Nature Genetics $2000 \mathbf{2 5} 182-186$.

5 Machinis K, Pantel LJ, Netchine I, Leger J, Camand OJA, Sobrier M-L et al. Syndromic short stature in patients with germline mutation in the LIM homeobox LHX4. American Journal of Human Genetics 200169 961-968.

6 Duquesnoy P, Roy A, Dastot F, Ghali I, Teinturier C, Netchine I et al. Human Prop 1: cloning, mapping, genomic structure. Mutations in familial combined pituitary hormone deficiency. FEBS Letters $1998 \mathbf{4 3 7} 216-220$.

7 Li S, Crenshaw EB III, Rawson EJ, Simmons DM, Swanson LW \& Rosenfeld MG. Dwarf locus mutants lacking three pituitary cell types result from mutations in the POU-domain gene Pit1. Nature $1990347528-533$.

8 Wu W, Cogan JD, Pfäffle RW, Dasen JS, Frisch H, O'Connell SM et al. Mutations in PROP1 cause familial combined pituitary hormone deficiency. Nature Genetics 199818 147-149.

9 Fofanova O, Takamura N, Kinoshita E, Parks JS, Brown MR, Peterkova VA et al. Compound heterozygous deletion of the PROP-1 gene in children with combined pituitary hormone deficiency. Journal of Clinical Endocrinology and Metabolism 1998 $832601-2604$.

10 Osorio MGF, Kopp P, Marui S, Latronico AC, Mendonca BB \& Arnhold IJP. Combined pituitary hormone deficiency due to a mutation of a highly conserved residue (F88S) in the homeodomain of PROP-1. Journal of Clinical Endocrinology and Metabolism $2000852779-2784$.

11 Agarwal G, Bhatia V, Cook S \& Thomas PQ. Adrenocorticotropin deficiency in combined pituitary hormone deficiency patients homozygous for a novel PROP1 deletion. Journal of Clinical Endocrinology and Metabolism $2000 \mathbf{8 5} 4556-4561$.

12 Vallette-Kasic S, Barlier A, Teinturier C, Diaz A, Manavela M, Berthezène $\mathrm{F}$ et al. PROP1 gene screening in patients with multiple pituitary hormone deficiency reveals two sites of hypermutability and a high incidence of corticotroph deficiency. Journal of Clinical Endocrinology and Metabolism 2001 86 4529-4535.

13 Riepe FG, Partsch CJ, Blankenstein O, Monig H, Pfäffle RW \& Sippell WG. Longitudinal imaging reveals pituitary enlargement preceding hypoplasia in two brothers with combined pituitary hormone deficiency attributable to PROP1 mutation. Journal of Clinical Endocrinology and Metabolism 2001 86 4353-4357.

14 Vieira TC, Dias da Silva MR, Cerutti JM, Brunner E, Borges M, Arnaldi LT et al. Familial combined pituitary hormone deficiency due to a novel mutation $\mathrm{R} 99 \mathrm{Q}$ in the hot spot region of prophet of Pit-1 presenting as constitutional growth delay. Journal of Clinical Endocrinology and Metabolism $2003 \mathbf{8 8} 38-44$.

15 Paracchini R, Giordano M, Corrias A, Mellone S, Matarazzo P, Bellone J et al. Two new PROP1 gene mutations responsible for compound pituitary hormone deficiency. Clinical Genetics 2003 $64142-147$.

16 Dattani MT \& Robinson IC. The molecular basis for developmental disorders of the pituitary gland in man. Clinical Genetics 200057 337-346.

17 Cushman LJ, Showalter AD \& Rhodes SJ. Genetic defects in the development and function of the anterior pituitary gland. Annals of Medicine 200234 179-191.

18 Pernasetti F, Toledo SP, Vasilyev VV, Hayashida CY, Cogan JD, Ferrari $\mathrm{C}$ et al. Impaired adrenocorticotropin-adrenal axis in combined pituitary hormone deficiency caused by a two-base pair deletion (301-302delAG) in the prophet of Pit-1 gene. Journal of Clinical Endocrinology and Metabolism 2000 85 390-397.

19 Asteria C, Oliveira JHA, Abucham J \& Beck-Peccoz P. Central hypocortisolism as part of combined pituitary hormone deficiency due to mutations of Prop-1 gene. European Journal of Clinical Endocrinology $2000143347-352$.

20 Voutetakis A, Livadas S, Sertedaki A, Maniati-Christidi M \& Dacou-Voutetakis C. Insufficient adrenarche in patients with combined pituitary hormone deficiency caused by a PROP-1 gene defect. Journal of Pediatric Endocrinology and Metabolism 200114 1107-1111.

21 Mendonca BB, Osorio MG, Latronico AC, Estefan V, Lo LS \& Arnhold IJ. Longitudinal hormonal and pituitary imaging changes in two females with combined pituitary hormone deficiency due to a deletion of A301, G302 in the PROP1 gene. Journal of Clinical Endocrinology and Metabolism $1999 \mathbf{8 4}$ 942-945.

22 Fofanova O, Takamura N, Kinoshita E, Vorontsov A, Vladimirova V, Dedov I et al. MR imaging of the pituitary gland in children and young adults with congenital combined pituitary hormone deficiency associated with PROP1 mutations. American Journal of Roentgenology 2000174 555-559.

23 Teinturier C, Vallette S, Adamsbaum C, Bendaoud M, Brue T \& Bougneres PF. Pseudotumor of the pituitary due to a PROP-1 deletion. Journal of Pediatric Endocrinology and Metabolism 2002 15 95-101.

24 Argyropoulou M, Perignon F, Brunelle F, Brauner R \& Rappaport R. Height of normal pituitary gland as a function of age evaluated by magnetic resonance imaging in children. Pediatric Radiology $199121247-249$.

25 Tsunoda A, Okuda O \& Sato K. MR height of the pituitary gland as a function of age and sex: especially physiological hypertrophy in adolescence and in climacterium. American Journal of Neuroradiology $199718551-554$.

26 Krude H, Biebermann H, Schnabel D, Ambrugger P \& Grüters A. Molecular pathogenesis of neonatal hypothyroidism. Hormone Research 200053 (Suppl 1) 12-18.

27 Sertedaki A, Papadimitriou A, Voutetakis A, Dracopoulou M, Maniati-Christidi M \& Dacou-Voutetakis C. Low TSH congenital hypothyroidism: Identification of a novel mutation of the TSH $\beta$-subunit gene in one sporadic case (C85R) and of mutation Q49stop in two siblings with congenital hypothyroidism. Pediatric Research 200252 935-940.

28 Bonomi M, Proverbio MC, Weber G, Chiumello G, Beck-Peccoz P \& Persani L. Hyperplastic pituitary gland, high serum glycoprotein hormone $\alpha$-subunit, and variable circulating thyrotropin (TSH) levels as a hallmark of central hypothyroidism due to mutations of the TSH $\beta$ gene. Journal of Clinical Endocrinology and Metabolism 200186 1600-1604.

29 Parks JS, Brown MR, Hurley DL, Phelps CJ \& Wajnrajch MP. Heritable disorders of pituitary development. Journal of Clinical Endocrinology and Metabolism $1999 \mathbf{8 4} 4362-4370$.

30 Altschul SF, Madden TL, Schäffer AA, Zhang J, Miller W \& Lipman DJ. Gapped BLAST and PSI-BLAST: a new generation of protein database search programs. Nucleic Acids Research 1997 25 3389-3402.

31 Frischmeyer PA \& Dietz HC. Nonsense-mediated mRNA decay in health and disease. Human Molecular Genetics $1999 \mathbf{8}$ 1893-1900.

32 Cogan JD, Wu W, Phillips JA 3rd, Arnhold IJ, Agapito A, Fofanova OV et al. The PROP1 2-base pair deletion is a common cause of combined pituitary hormone deficiency. Journal of Clinical Endocrinology and Metabolism 199883 3346-3349.

33 Flück C, Deladoëy J, Rutishauser K, Eblé A, Marti U, Wu W et al. Phenotypic variability in familial combined pituitary hormone deficiency caused by a PROP1 gene mutation resulting in the substitution of Arg $\rightarrow$ Cys at codon 120 (R120C). Journal of Clinical Endocrinology and Metabolism $1998 \mathbf{8 3} 3727-3734$. 
34 Persani L, Ferretti E, Borgato S, Faglia G \& Beck-Peccoz P. Circulating TSH bioactivity in sporadic central hypothyroidism. Journal of Clinical Endocrinology and Metabolism 2000 $853631-3635$.

35 Clarke EA, Yates P \& Goldie DJ. Hypothyroidism: an important differential diagnosis for raised serum transaminases? Journal of Clinical Pathology 198942 1226-1227.

36 Vaughters RB Jr. Hypothyroidism as a cause of enzyme elevations. Journal of the South Carolina Medical Association $1990 \mathbf{8 6}$ 351-352.

37 Elmlinger MW, Kühnel W \& Ranke MB. Reference range for serum concentrations of leutropin (LH), follitropin (FSH), estradiol (E2), prolactin, progesterone, sex hormone binding globulin (SHBG), dehydroepiandrosterone sulfate (DHEAS), cortisol and ferritin in neonates, children and young adults. Clinical Chemistry and Laboratory Medicine 200240 1151-1160.

38 Parks JS, Baumbach L, Sanchez JC, Stanley CA \& Gianella-Neto D. Natural history and molecular mechanisms of hypopituitarism with large sella turcica. In Proceedings of the 80th Annual Meeting of the Endocrine Society, p 470. Bethesda, MD: Endocrine Society Press, 1998.

Received 16 October 2003

Accepted 24 November 2003 